\title{
Cancer Diagnostic Practices Have Seen a Transformation in the Last Few Years- Explore the Scenario
}

\author{
Ashish Gujrathi \\ Allied Market Research, Viman Nagar Pune Sainik Nagar, Somnath Nagar, Wadgaon Sheri, Maharashtra, India.
}

Corresponding Author: Ashish Gujrathi, Allied Market Research, Viman Nagar Pune Sainik Nagar, Somnath Nagar, Wadgaon Sheri, Maharashtra, India.

Received date: August 05, 2021: Accepted date: August 10 2021: Published date: August 28, 2021

Citation: Ashish Gujrathi (2021) Cancer Diagnostic Practices Have Seen a Transformation in the Last Few Years- Explore the Scenario J. Clin Case Rep and Stu 2(5); DOI: 10.31579/2690-8808/087

Copyright: () 2021 Ashish Gujrathi. This is an open access article distributed under the Creative Commons Attribution License, which permits unrestricted use, distribution, and reproduction in any medium, provided the original work is properly cited.

\section{Editorial}

Identifying cancer at the early stages does offer several chances for a cure. Cancer diagnostics can be defined as a process of detecting proteins, biomarkers, and certain marks that help in proper spotting of a malignant tumor in body. For quite a few malignant cases, studies and surveys reveal that screening tests have often proved to be highly beneficial for the detection. However, for other types, screening tests are suggested only for patients with bigger risk factors.

There are several guidelines and procedures for cancer screening and they tend to vary from organization to organization. A doctor or a medical practitioner take recourse to different approaches to identify cancers and they take in biopsy, imaging tests (CT scans, colonoscopy, mammography etc.), lab tests, and physical exam. Lately, researchers have also come up with a more advanced procedure, namely molecular diagnostics that can spot explicit cancer-associated molecules that flow in bodily solutions such as urine and blood.

Engineers from MIT (Massachusetts Institute of Technology) have now formed a novel diagnostic nano scale particle that can divulge the existence of malignant proteins through urine checks, and it performs as an imaging medium, identifying the tumor location. In a nutshell, this diagnostic could be best utilized to distinguish cancer anywhere in the body; it can also extricate tumors that have spread to a different body part from their original locations.

The broad sensor is especially fabricated to acknowledge to both primary growths \& lumps and their metastases. When it elicits a urinary signal, it also allows one to envisage where exactly the tumors are. Moreover, in a new revelation, the diagnostic is further shown to be used to detect the development of colon cancer, counting the binge of metastatic polyps to different body parts including the lung and the liver. Finally, it is expected that the diagnostic would soon develop into a routine cancer detection that could be performed every year.

Unilabs, one of the renowned international benefactor of diagnostic solutions, has recently signed a deal with Ibex Medical Analytics, to set up more advanced diagnostic practices that are powered with Artificial
Intelligence. Both the ventures have happened to settle on a term to carry out Ibex's AI policy in pathology laboratories all over Europe. Initiating with a national deployment in Sweden, Unilabs is planning to take along Ibex's AI platform to almost sixteen other nations. Unilabs has been considered as the first diagnostic service provider in Europe to set up Ibex's Galen ${ }^{\mathrm{TM}}$ platform, offering the physicians as well as the patients a more swift and more precise identification, thereby streamlining the overall cancer treatment when it is needed the most.

As per the specialists, this avant-garde AI enabled technology will help the practitioners quickly line up vital cases, expedite diagnosis, and enhance the overall quality by incorporating an additional set of digital eyes. Especially when it's about malignancy, the earlier it gets diagnosed, the better would be the result. Thus, acquiring critical results quicker and sooner will not only help save more lives, but would also pave the way toward better and more advanced medical interface.

Taking resort to algorithms developed with cutting-edge machine learning technology, the Ibex platform is positioned to identify cancer and other clinical issues. The algorithms are set in a way that it would automatically evaluate images from cell removals, doling out proper insights to pathologists who analyze the case and whose valuation is important for reaching out the ideal treatment decisions by the doctors. Most importantly, the real-time quality control and the highly enhanced diagnostic procedures would certainly create a benchmark for the pathologists all over the world.

According to Allied Market Research, the global cancer diagnostics market is anticipated to cite a significant CAGR from 2021 to 2028. In the last few years, there has been huge rise in the prevalence of different types of cancer, especially lung cancer and breast cancer, which in turn has worked as a major driver for the growth of the market. Moreover, significant advancements in the realm of technology have helped with better imaging of oncogenic cells. Development and enhancement in equipment to categorize the type of cancer, and surge in effectiveness of the result are also expected to help the cancer diagnostics sector to procure huge traction in the coming years. Rise in government initiatives to lay out awareness about early diagnosis of cancer is projected to augment the market growth in the coming years. At the same time, increase in the 
number of diagnostics centers in the developed economies has been highly beneficial for the growth of the market. Moreover, several regulations \& dictums in terms of health and safety and rise in acceptance toward yoga and other healthy practices are projected to pave the way for lucrative opportunities for the frontrunners in the industry.

Here, it's worth mentioning that the outbreak of COVID-19 led to global lockdown, especially in the initial phase, and the extensive financial impact proved to be detrimental to the growth of the neurology clinics, as most hospitals happened to experience a steep decline in patient visits during the pandemic, thereby decreasing client contacts altogether. Simultaneously, the fact that restricted availability of proper care for medical conditions other than COVID-19 affected the global market cancer diagnostics in more than one way. Also, dearth in availability of healthcare staff in most countries impacted the market negatively. However, the global situation is being ameliorated at a slow \& steady pace and the market is expected to revive soon.

Author's Bio- Koyel Ghosh is a blogger with a strong passion and enjoys writing on miscellaneous domains, as she believes it lets her explore a wide variety of niches. She has an innate interest for creativity and enjoys experimenting with different writing styles. A writer who never stops imagining, she has been serving the corporate industry for the last four years.

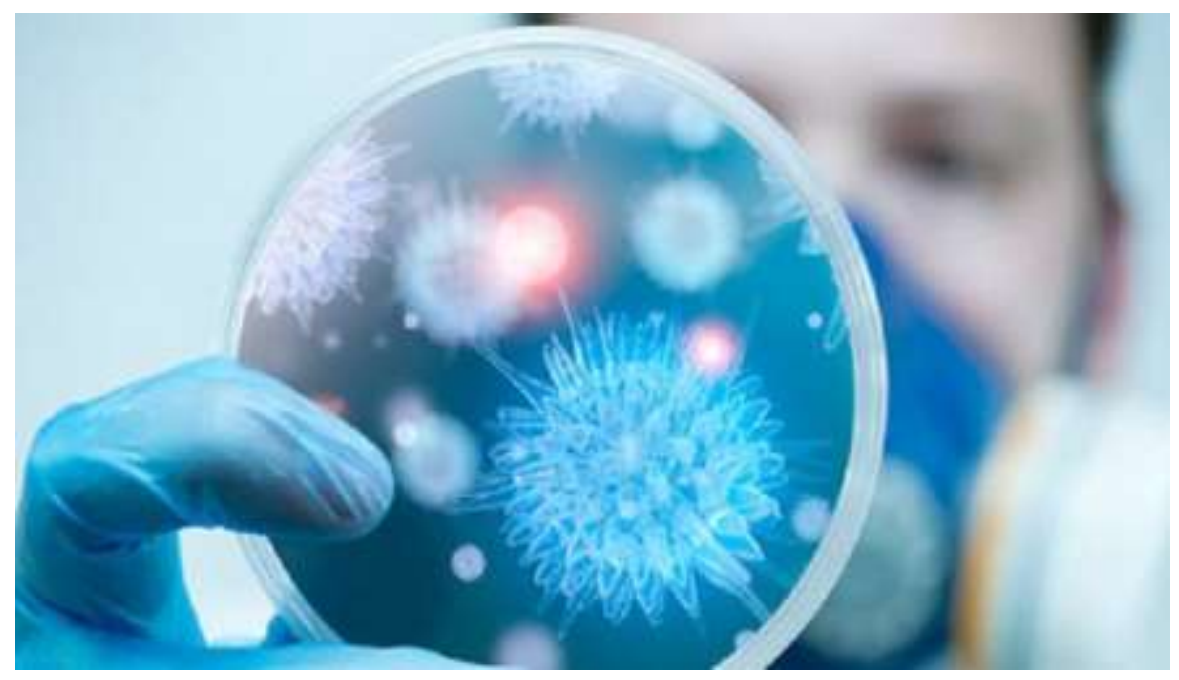

This work is licensed under Creative Commons Attribution 4.0 License

\section{To Submit Your Article Click Here: Submit Manuscript}

DOI: $10.31579 / 2690-8808 / 087$

\footnotetext{
Ready to submit your research? Choose Auctores and benefit from:

fast, convenient online submission

* rigorous peer review by experienced research in your field

* rapid publication on acceptance

* authors retain copyrights

* unique DOI for all articles

* immediate, unrestricted online access
}

At Auctores, research is always in progress.

Learn more www.auctoresonline.org/journals/journal-of-clinical-casereports-and-studies 